\title{
5 \\ Associations Freely Chosen: New Geopolitics in the North Pacific
}

\author{
Gerard A. Finin
}

\section{A new era}

For the first time since the collapse of the Soviet Union, America's global leadership is being directly challenged. In Asia, blunt trade policies imposed upon China by the Trump administration had raised the spectre of a trade war. United States' withdrawal from the critically important Paris Climate Agreement during the Trump years prompted widespread condemnation by the global community, particularly from Pacific Island nations. President Trump's advocacy of unabashed US unilateralism also generated tensions with European allies, including close partners that for generations cooperated with the US in maintaining stability.

In contrast, the 2020 election of President Joseph Biden is all but certain to usher in a return to the Obama administration's emphasis on multilateralism to advance peace and stability, consciously avoiding the hairpin policy turns, contradictions and befuddlement evident over the last four years. One of the Obama administration's flagship foreign policy initiatives was its 'rebalance' or 'pivot' towards the Asia-Pacific, a decision that reflected long-term economic and demographic trends. The historically robust US military presence across the Asia-Pacific region was balanced by multinational military exercises, the proposed Trans-Pacific 
Partnership trade agreement and enhanced public diplomacy. Although the rebalance was clearly articulated during the Obama administration's first term by secretary of state Hillary Clinton, there were in retrospect insufficient concrete actions to impart real credibility. At best, the pivot remained largely aspirational, and never gained traction as a true transformation in US foreign policy. With many of the same individuals who initially conceived the 'rebalance' now back in government, analysts are asking whether the 'rebalance' will in some form be resurrected?

Despite stark differences in approach and style compared to his predecessors, the Trump administration continued to pursue US power projection across this vast area-a pillar in America's westward strategy with roots dating back to the late 19th century (Anderson 2015). What distinguished the Trump administration was its sharp focus on potential threats from China as it attempted to amplify the US's profile and presence across the renamed Indo-Pacific region. However deep the contemporary political divisions with the US may be, there is broad agreement that China cannot be left unchallenged. China's increasingly authoritarian state is viewed as an aggressive threat to the regional order that must be confronted. The Biden administration's change in tone and policy branding will do little to alter the Trump administration's deployment of the full array of US government departments and agencies operating under the loosely constructed, and at times contradictory, Free and Open Indo-Pacific Strategy (Roy 2019).

Consistent with this new thinking about China's motivations in Oceania are New Zealand's Pacific Reset and Australia's Pacific Step-Up initiatives, both designed to counter the People's Republic of China's (PRC) desire to play a larger role in the Pacific Islands region. And even if the US has yet to clearly define what it is now calling the 'Pacific Pledge', there can be little doubt that this is a transformational moment in the Pacific region, with Australia, New Zealand and the US anticipating a much more highly competitive era. While slow in gaining full momentum, the new 'whole of government' responses to China's rise by Western powers are increasingly evident in Oceania as well as across the Indo-Pacific more broadly. The Biden administration's National Security Council point person for Indo-Pacific strategy advocates 'the need for a balance of power; the need for an order that the region's states recognize as legitimate; and the need for an allied and partner coalition to address China's challenges to both' (Campbell and Doshi 2021:1). 
Evidence of this change has been apparent in Washington well before the 2020 presidential election. For instance, in March 2019 senior White House staff, including the senior director for Asian affairs and the director for Oceania and Indo-Pacific Security on the National Security Council visited Vanuatu and Solomon Islands for meetings with top officials. Other indications of intensifying US focus in the region in 2019 include a sharp uptick in funding for public diplomacy programs, new military to military initiatives between the Pentagon and Fijis armed forces and visits to the region by US congressional delegations. New Pacific Island activities among Washington-based research and educational institutions such as the Hudson Institute and Georgetown University's Center for Australian, New Zealand and Pacific Studies suggest interest is by no means limited to government. ${ }^{1}$

\section{High-level North Pacific engagement}

The effort to stem Chinese influence in the North Pacific was evident in a February 2019 statement by US Secretary of State Mike Pompeo addressing the foreign policies of two North Pacific nations that have a special 'free association' agreement with the US. Both the Republic of the Marshall Islands (RMI) and the Republic of Palau (Palau) were commended for positions clearly at variance with US policy regarding official recognition of Taiwan. Quoting the US vice president, Secretary Pompeo said:

America will always believe Taiwan's embrace of democracy is an example to be internationally supported. We respect and support the decision those of you have made to continue to support Taiwan.

Left completely out of the statement was any mention of the Federated States of Micronesia (FSM), the largest nation in Free Association with the US, and the only North Pacific Island nation that, like Washington, recognises the PRC. Shortly thereafter, however, a senior delegation of US

\footnotetext{
1 These activities include seminars and roundtable dialogues focusing on Oceania's evolving strategic position. Similarly, the DC-based Center for Strategic and International Studies recently convened a Strengthening the US-Pacific Islands Partnership workshop in Fiji that brought together a who's who of Oceania's regional organisations. An example of the increase in Pacific-focused publications is a recent Hudson Institute paper on the use of foreign aid to counter China's Djibouti Strategy (Lee 2019). Additional evidence of US military activity is the deployment of some 200 US troops to Palau for an exercise known as Pacific Pathways.
} 
military, coast guard and Department of the Interior officials travelled to meet with leaders of the FSM (as well as FSM's Chuuk State Government) before also visiting Palau and the RMI (Radio New Zealand 2019).

President Donald Trump subsequently convened an unprecedented working-level meeting at the White House on 21 May 2019 with Presidents Hilda Heine of the RMI, David Panuelo of the FSM and Tommy Remengesau of Palau. The brief Oval Office discussion and photo opportunity was intended to advance Compact of Free Association economic support renewal negotiations before the 2023-24 deadlines. Just a few days prior to the White House event, President Remengesau, in an op-ed article published by The Hill (2019), noted how China 'has risen as a serious challenge to US dominance of the Pacific Ocean today'. While in Washington, President Heine similarly focused her remarks on Chinese pressure, including incursions within the RMI's Exclusive Economic Zone related to the illegal entry of fishing vessels.

Since re-establishing diplomatic relations with Beijing in 1979, Washington has kept Taiwan at arm's length politically, as it saw far greater prospects for advancing US interests through relations with the PRC. However, China's rapid rise as a global power intent on charting its own course has in more recent years created a range of diplomatic and economic frictions. This includes its renewed emphasis on reincorporating Taiwan into its body politic as part of the One China principle. Under President Xi Jinping, it is clear that of the thousands of islands across the Indo-Pacific, the Austronesian island state that matters most to Beijing is Taiwan. Few scholars dispute that the PRC is resolute in its determination to bring Taiwan within Beijing's direct control. Standing in opposition to Beijing's plans are four sovereign Pacific Island nations, including the RMI and Palau, that at least for now appear unwavering in their recognition of Taiwan. ${ }^{2}$ This support for Taiwan, coupled with plans announced by the US in 2004 to greatly reduce economic support to the FSM and the RMI, has encouraged Beijing to increase diplomatic and economic activities in the North Pacific.

2 Early in 2019, President Xi made this clear to officials and military leaders seated in the Great Hall of the People when he stated, 'The country is growing strong, the nation is rejuvenating and unification between the two sides of the strait is the great trend of history'. Later in the address he asserted, "We make no promise to abandon the use of force and retain the option of taking all necessary measures' (Buckley and Horton 2019). 
While some analysts may see US-PRC competition in the Pacific Islands region as a mere replay of the Cold War, when Soviet diplomatic and naval activities prompted a sharp US reaction, the dynamics of the USChina relationship are far more complex. To better understand the larger geopolitical developments across Oceania, this chapter explores how USChina relations are evolving in the three Freely Associated States (FAS) of the North Pacific and suggests how and why US policy in the FAS reflects larger trends in US-China relations.

\section{Background}

America has not been overtly challenged militarily in the Pacific Islands region since the US concluded World War II. US activities in the North Pacific were especially free of geostrategic constraints because of large US military installations in Hawai $i$, Guam and the Philippines. Under United Nations (UN) auspices, in 1947 the Trust Territory of the Pacific Islands (TTPI) was created where Japan had once ruled (Hezel 2003). The UN gave exclusive authority for governing the TTPI to the US. In time, nearly all of this island constellation would become the three FAS, each having a treaty-like agreement or 'compact' with the US guaranteeing unilateral and unfettered US military access. During the post-war decades, the RMI was the site for 67 nuclear tests, while the Northern Marianas reportedly served as a counter-insurgency training location for missions in Southeast Asia and for support of the Chinese Nationalist Party based in Taiwan. With the US represented in the South Pacific by American Samoa, as well as close bilateral ties with Australia, Britain, France and New Zealand, the entire Pacific Islands region during the post-war decades came to be seen by many US policymakers as an 'American lake' (Underwood 2017). ${ }^{3}$

The slow pace of TTPI economic development and Cold War pressures during the 1960s and 1970s brought about a dramatic per capita increase in US funding for the TTPI. Historian David Hanlon assessed the failures of these financial infusions when he observed:

3 In the words of former US congressman Robert Underwood (2017), 'The absolute arrogance of these activities was given various justifications at the time. It was classic imperialist exploitation papered over with the flimsiest of authority. As we look at those days, the old saying in the Trust Territory comes to mind. The islanders had the trust and the Americans had the territory'. 
The messy entanglements that marked efforts at economic development by the mid-1970s resulted in part from Trust Territory government offices, federal bureaucracies and international aid agencies working at cross-purposes or against one another in institutionally prescribed ways in the development game (1998:237).

If the initiatives to stimulate economic development fell short of stated goals, the US-led efforts to establish vibrant democratic institutions with elected representative bodies met far greater success. Similarly, the establishment of public educational institutions (from primary through community colleges) and cultural exchanges (e.g. the Peace Corps) saw significant gains (Stayman 2009).

A UN-monitored vote in the late 1970s subsequently offered TTPI residents the opportunity to formally become an unincorporated part of the US. This was rejected by most of the TTPI districts (Levy 2008). Therefore, during the mid-1980s and through the early 1990s, the TTPI structure transitioned to a new arrangement wherein three new nation states and one commonwealth were created. The Northern Mariana Islands chose to become a commonwealth of the US, with a legal status similar to that of Puerto Rico. The RMI and Palau, each embracing considerable cultural homogeneity, voted to become sovereign unitary republics. The more culturally diverse FSM was created by establishing four state governments within one country: Chuuk, Kosrae, Pohnpei and Yap.

What is distinctive about the US's relationships with these three countries is the special bilateral agreements that were created to maintain close and mutually beneficial ties. The idea of free association was first established between New Zealand and two neighbouring South Pacific nations, Cook Islands (1965) and Niue (1974). Self-government in free association provided greater sovereignty and independence for the smaller developing nations without hindering visa-free movement to the larger nation for residency, employment or education. ${ }^{4}$ With some modifications, this served as the model for the three newly established nations in the North Pacific.

4 While Cook Islanders and Niueans elect their own parliaments and national leaders, they travel internationally with New Zealand passports. This has complicated their desire to have UN representation. 
Following independence, the FSM, the RMI and Palau, despite initial US reluctance, joined the UN and other international institutions with full membership rights and responsibilities. At the same time, the compacts of free association in the North Pacific provided for continued US economic assistance and exclusive US military access. Importantly, in keeping with the principles of sovereignty and self-government, each party retains the right to unilaterally withdraw from the free association agreement (Stayman 2009:9). Despite the obvious asymmetries between the interactions of a continental power and smaller states, the basic US relationship with the three FAS advances the national interests of each of the parties to the compacts. Over some three decades, none of the signatory nations have ever taken steps indicating they wish to abrogate their respective free association agreement.

\section{Early years of nationhood}

The first compacts of free association were signed by the US with the FSM and the RMI in 1986. An impasse over proposals to make Palau nuclear free delayed its independence until 1994. US budgetary and program support to the FSM and the RMI from 1987 through 2003 is estimated to have totalled US $\$ 2.1$ billion. For a total population of less than 160,000 , this represented approximately US\$900 per capita basis on an annual (Finin 2013:24).

The success of the FAS in developing vibrant democratic political institutions contrasts with the ongoing challenges of creating more self-reliant economies, particularly in the FSM and the RMI. A number of post-independence initiatives to stimulate these economies, such as the establishment of domestic fishing fleets, fared poorly (Hezel 2006). An in-depth assessment of the economic support provisions of the FSM and the RMI compacts by the US General Accountability Office (US GAO) in 2003 found that:

many Compact-funded projects in the FSM and RMI experienced problems because of poor planning and management, inadequate construction and maintenance, or misuse of funds. Further, the US, FSM, and RMI provided little accountability over Compact expenditures and have not ensured that funds were spent effectively or efficiently (2018:1). 
The initial 15 years of the FSM's and the RMI's independence (often termed Compact I) demonstrated the complexities of island development in an environment with limited capacities and young institutions. At the same time, it underscored the need make development investments more effective. Following prolonged negotiations focusing on mechanisms to ensure greater accountability of US funds, Compact II (2004-23) created a new structure for US economic support with an emphasis on the health and education sectors.

Under the new Compact II arrangement, five-person economic management committees were established for each country. Membership in the FSM's Joint Economic Management Committee (JEMCO) and the RMI's Joint Economic Management and Financial Accountability Committee (JEMFAC) was composed of three US members and two from each of the respective countries. This imbalance in JEMCO and JEMFAC representation, seen by many as a neocolonial imposition, was described by former US congressman Robert Underwood of Guam as 'less free and more compact' (2003). From the perspective of the FSM and the RMI, there were perhaps fewer anxieties about the stricter process of review and approval for the expenditure of compact funds (US\$3.6 billion in economic assistance 2004-23) than were concerns regarding deep infringements of national sovereignty. To many observers, the JEMCO and JEMFAC structures suggested less collegiality and amity in working toward common development goals, reintroducing a process more akin to pre-independence TTPI-style budgetary rule.

Furthermore, Compact II required the establishment of trust funds for each nation. The trust funds were strongly suggestive of US thinking about its future relationships with the FSM and RMI. Widely interpreted as an economic exit strategy for the US, Compact II specified a schedule of reduced annual US treasury flows (called decrements) for recurrent government expenditures (e.g. public worker salaries, government program budgets) and an increase in funds deposited annually into the trust funds' accounts. These accounts were intended to create an investment pool sufficient to generate the income needed to sustain the FSM's and the RMI's fiscal requirements after the economic support provisions of the compacts expire. The yearly decrements in US funding for recurrent expenditures soon forced the FSM and the RMI to attempt budget cuts while simultaneously seeking alternative sources of revenue and economic support. 
An analysis of the trust funds by the US GAO published before the 2008 global economic crisis foresaw management challenges and market volatility that would call into question projected revenue streams (US GAO 2007). A subsequent 2018 US GAO analysis of actions needed to prepare for the post-2023 transition to trust fund income concluded that 'the trust funds are increasingly likely to provide no annual disbursements in some years and to not sustain their value' (2018:1).

Even before this most recent report, however, both the FSM and the RMI sought assistance from other countries. For instance, in 2008 and 2010 FSM reportedly deposited US\$1 million from Chinese grants in the FSM Trust Fund. The RMI established its own trust fund under an agreement with Taiwan wherein US\$10 million was contributed as an initial corpus. By 2017 , this fund had grown to US $\$ 15.1$ million (US GAO 2018:79-80).

In light of the looming scheduled deadline for major US economic support to end, the FSM and the RMI have explored new economic development opportunities. For example, in 2018 the RMI took preliminary steps to embrace digital currency as a way to attract more economic activity, pulling back only when International Monetary Fund officials warned of significant dangers (Baraniuk 2018). Although it is highly likely that agreement with the US will be reached, both countries have carefully assessed what the potential vacuum in economic support could mean for their future bilateral relationships with the US and other nations.

In contrast to its neighbours, the Republic of Palau has a record of strong economic growth and fiscal performance that places it as one of the Pacific Islands' only upper middle-income countries. Its per capita gross national income of US $\$ 13,950$ (2017) is more than three times that of FSM's and more than twice that of the RMI's. ${ }^{5}$ Its trust fund, established at the time of independence in 1994, was valued at an estimated US\$184 million in 2015. The extended eight-year delay in the passage of US congressional legislation providing economic support, initially promised in 2010, has been resolved. This has once again set the relationship between the two countries on solid footing for renewal prior to the 2024 deadline.

5 See pacificaidmap.lowyinstitute.org. 
Viewed as a whole, the bilateral ties between the US and the three countries with free association relationships are generally positive, with US embassies in each of the capitals facilitating regular communication and monitoring the work of numerous US federal agencies. Still, there can be little doubt that the eventual withdrawal of major US funding to the FSM and the RMI creates uncertainty about the future and encourages both nations to explore new forms of engagement with existing allies or potential new partners.

\section{Current US security interests}

For well over seven decades, the Pacific has been seen as critical to US national security and other core US interests in the region. The compacts of free association in the northwest Pacific provide for exclusive US access to the waters, land and airspace over an area of more than 5,590,460 square kilometres, an expanse nearly as large as the continental US. ${ }^{6}$ Catalysed by China's ambitions, as well as the changing geostrategic environment across the Pacific generally, the US is currently reassessing its relations with the FAS. To a greater extent than ever before, these three sovereign island nations are gaining both voices and negotiating leverage with some of the world's most powerful nations (Wesley-Smith and Porter 2010).

The US views the FAS as peaceful, stable democracies that regularly hold free and fair elections and maintain commendable human rights records. There has never been civil unrest or disruptions of the constitutional processes comparable with those of some neighbouring allies such as the Philippines. Within the UN, the voting records of the FSM, the RMI and Palau are ranked as being among the most consistent with positions taken by the US. Citizens of the FAS value their visa-free access to the US for purposes of study, work or residency without time limitations. In light of the US taking responsibility for their national defence, the FAS are able to focus on domestic issues such as health and education. Qualified citizens of the FAS are eligible to join the US military, with increasing numbers serving in all branches of the armed forces stationed around the globe. ${ }^{7}$

6 CIA World Factbook. See also, www.seaaroundus.org.

7 See, for example, Nathan Fitch's 2018 documentary about the FSM's citizens in the US military, Island Soldier. www.islandsoldiermovie.com 
Though all three countries have some similarities, it is important to distinguish analytically between the FSM, the RMI and Palau, as the strategic importance of each to the US must be seen through a separate lense. There is little doubt, for example, that the major billion-dollar investments in US military assets in the RMI's Kwajalein are unrivalled in the region. Similarly, the economic trajectories of the three FAS are distinctive, with Palau having developed a thriving private sector fuelled by its tourism industry. Foreign policies and diplomatic relations also vary. As noted previously, only the FSM formally recognises China, while Palau and the RMI both have long-standing diplomatic relations with Taiwan. However, to a greater degree than ever before, China seeks enhanced engagement with the FSM and is simultaneously pushing to advance its One China policy in the RMI and Palau.

Critical to understanding the dynamics that underlie contemporary developments are two separate but related issues, both concerned with US security interests. With the current economic support arrangements between the US and the FSM and the RMI set to expire in just three years, there are major economic uncertainties. FSM compact sector and supplemental education grants ending in 2023 comprise 33 per cent of the government's total expenditures. The RMI compact sector and supplemental education grants ending in 2023 constitute 25 per cent of the government's total expenditures (US GAO 2018:20-22). Such a significant reduction in US budgetary support to the FSM and the RMI, if matched by a proportionate reduction in government services, has the potential to disrupt social and political stability. ${ }^{8}$

At the same time, the US is currently seeking to bolster its military capabilities in the FAS through new infrastructure and signals installations. Such enhancements to the strategic posture of the US, particularly in relation to the PRC's island-building activities in the South China Sea, are of increasing priority. Palau's President Remengesau unequivocally welcomed a larger US military presence, stating that all three Freely Associated States are 'natural allies in the Pentagon's new Indo-Pacific strategy' (2019).

8 Moreover, both countries may lose population. The visa-free access to the US provided by the compacts of free association could, in the face of diminished public services and economic uncertainty, lead to increased out-migration, especially among those citizens with marketable skills. Over time, the majority of the FSM's and the RMI's citizens may choose to reside in the US, conceivably prompting the two island governments to adopt policies that encourage more skilled in-migration from other Asia-Pacific nations. This is already the case for Cook Islanders and Niueans in the South Pacific, where there is a free association structure with New Zealand. 
As the US confronts a fast-changing geopolitical environment across the Indo-Pacific, it is clear that 2023-24 represents a significant juncture. This date offers policy options for economic decoupling with the FAS or, alternatively and more likely, opportunities to bolster bilateral relations through new economic support structures. It appears highly probable that the once-heralded plans for significant decreases in US economic support to the FSM and the RMI will be cast aside in favour of realpolitik. This new environment offers the FAS unprecedented opportunities to advance their respective national interests.

\section{Overseas development assistance in the Freely Associated States}

After more than a decade of implicit agreement by China and Taiwan to maintain the status quo in terms of diplomatic ties, changes in Taiwan's internal political dynamics, reflected in the 2016 national elections, resulted in renewed competition for official recognition. The decisions by Kiribati and Solomon Islands in September 2019 to recognise China further altered the geostrategic currents. This strategic competition for the FAS is evident in aggressive diplomacy as well as expanding overseas development assistance (ODA). Concurrently, the increasingly competitive dynamic between China and the US has altered how US policymakers are thinking about future economic support in the North Pacific as well as new opportunities for cooperation with Taiwan.

Competition between Beijing and Taipei for diplomatic recognition has brought about intensified outreach efforts, such as aid project ribboncutting visits by Taiwan President Tsai Ing-wen to Palau and the RMI. This has been accompanied by other relationship-strengthening measures, including the signing of a visa-free entry agreement for the RMI's citizens (Radio New Zealand 2018a). Taiwan has also attempted to garner broader support within the region by demonstrating greater inclusiveness than China in education and training programs that allow individuals from all Pacific Island developing states to participate. ${ }^{?}$

9 This is seen, for example, in the scholarship program for the University of the South Pacific funded through the Pacific Islands Forum. 
The tension between Taiwan and China was evident in recent years during the Pacific Islands Forum meetings hosted by Palau in 2014 and the RMI in 2013. From the perspective of the Pacific Island nations, however, it is not the diplomatic skirmishes but the annual flows of ODA that are of far greater significance.

Neither China nor Taiwan participated in the 2009 Cairns Compact on strengthening ODA coordination and transparency in the Pacific. Both countries have eschewed collaborating with Western development initiatives in favour of charting their own independent courses in the Pacific (Finin 2011). Still, there is little doubt among Pacific Island aid specialists that Taiwan's overall aid program pales in comparison to China's. For China, the principles of South-South cooperation - equality, mutual benefit, common development and non-conditionality-have long been articulated as the basis for their ODA globally, and the Pacific is no exception (Kato et al. 2016:144). ${ }^{10}$

It is estimated by the Lowy Institute that in recent years China has spent nearly five times as much as Taiwan in the region. The most comprehensive estimates suggest China has expended US $\$ 1.26$ billion, while Taiwan has allocated US $\$ 224.03$ million. Moreover, China's projects are reported to be some nine times larger on average. Yet, from another perspective, Lowy's analysis found that because the countries that recognise Taiwan have much smaller populations, when viewed on a per capita basis, Taipei spends US\$237 to Beijing's US\$108 (Nguyen and Pryke 2018). Among the Pacific countries having smaller populations, such calculations may play a role in policymakers' decisions.

Participation in China's massive Belt and Road Initiative has been extended to each of the eight Pacific nations that recognise Beijing. However, the Beijing-based Taihe Institute recently warned that a number of Pacific Island nations would be bad or risky investments for Belt and Road projects (China Economic Review 2018). The possible leverage associated with such debt, as well as the burdens of debt service payments, has the potential to limit Pacific governments' future expenditures on basic needs. In the North Pacific, it appears the FSM has thus far resisted major loans from China (Greenfield and Barrett 2018).

10 Concessional and non-concessional financing by China, sometimes in cooperation with stateowned enterprises providing loans and investments, makes it difficult to distinguish what qualifies as ODA (Asplund and Soderberg 2017:108-14). 
President Xi Jinping's visit to Port Moresby for APEC's November 2018 meeting and his special side gathering with the leaders of Pacific Island countries that recognise Beijing allowed China to emphasise how potentially transformational Belt and Road Initiative projects could be for its diplomatic allies. Meanwhile, at the same APEC gathering, the US vice president appeared to depend heavily on Australian goodwill to announce 'joint cooperative' aid initiatives for the Pacific, suggesting USAID was not prepared to offer any major new projects to the region. From the perspective of numerous Pacific Island policymakers, Taiwan and other metropolitan donors will have to redouble their efforts as China becomes an increasingly influential Pacific power, both militarily and economically. Based on the recent decisions by Kiribati and Solomon Islands to recognise Beijing, it remains an open question whether Taiwan's intensified diplomatic efforts will continue to dissuade its remaining four Pacific allies from concluding that the current momentum and tide of history favours China.

Despite increasing activity by both China and Taiwan in the North Pacific, it is important to underscore that within the FAS, the US and the Western multilateral development banks it heavily supports remain by far the largest contributors to national development. Multilateral institutions appear more eager than ever before to broaden and deepen activities in Oceania. The Asian Development Bank (ADB) has announced plans to set up seven new offices around the region: Cook Islands, the RMI, the FSM, Palau, Nauru, Tuvalu and Kiribati will all are slated to have an ADB mission by the end of 2022. The ADB's portfolio of work in the region has doubled every five years since 2005. It currently stands at \$US2.9 billion, with total assistance expected to surpass \$US4 billion by 2020 (Radio New Zealand 2018b).

The World Bank's offices in Washington DC and Sydney both have growing programs with the FAS. A major region-wide research and publication effort focusing on 'Pacific Possible' includes an optimistic vision through 2040 for endeavours such as tourism, fisheries and labour mobility (World Bank 2017). Major World Bank investments are being made in information and communications technology, specifically the installation of fibre optic cables for broadband connectivity. By 2020, for instance, a US\$63.5 million connectivity project in FSM had connected Chuuk and Yap. The second phase of the project includes cables that will connect the republics of Nauru and Kiribati, and additional funding from the ADB will connect Kosrae (World Bank 2018). Considered as a whole, 
these recent developments suggest that there is more new development partner engagement in the North Pacific than at any time since the Cold War.

Still, it is widely acknowledged that the process of getting Western-funded projects off the ground in the FAS can at times be delayed by years. In some cases the delays are well justified, while in others it appears the approval process may be overly bureaucratic. For example, in 2016, US\$40 million in US compact fund expenditures for the RMI was approved, a reflection of the fact that from 2012-15, most compact infrastructure money was on hold. It was only with the aid of New Zealand-based engineers that dozens of stalled projects were finally launched (The Marshall Islands Journal 2017).

In contrast, there is a perception by many Pacific Island policymakers that China and Taiwan are both adept at fast-tracking priority projects. In the case of large infrastructure endeavours funded by China, this sometimes means that all materials and labour are shipped in for a project, allowing only minimal local input. But there is little doubt that the project will proceed without delay and be completed on schedule. A recent comparative study of ODA in Tonga and Vanuatu found that China's diplomats do not obscure the transactional nature of their relationship with the Pacific (Cheng and Taylor 2017). Moreover, compared to traditional ODA partners, there is ordinarily little conditionality and only minimal reporting requirements. Interestingly, it was noted that both China's and Taiwan's ambassadors appear to have greater discretionary spending authority than the ambassadors representing traditional aid donors such as the US, Australia, Japan and New Zealand (Funaki 2017). Close examination of specific activities within the three FAS helps illuminate the dynamics of diplomatic and economic relations on the ground.

\section{Federated States of Micronesia}

The FSM (population 103,000) established formal diplomatic ties with China in 1989. Since then, the relationship has grown, including the 2014 creation of the commission on economic trade cooperation. FSM's presidents have all consistently articulated adherence to the One China policy. In advancing their strategic goals, it is notable how China and Taiwan have gone beyond ODA chequebook diplomacy. Both have worked equally hard to cultivate Pacific Island leaders through official state visits featuring 
ceremonies that bestow status and prestige. The extensive formal protocol and high-level access to leaders during official visits by Pacific Island leaders to Beijing and Taipei is carefully observed across the region and is consistent with the practices often reserved for larger nation states.

Indicative of the level of attention China accords Pacific countries that maintain formal diplomatic relations was the March 2017 official state visit of FSM's then president Peter Christian. The well-planned event included a welcome ceremony at the Great Hall of the People with a full military review. A photograph showing both presidents being warmly greeted by flag-waving school children as they walked down a red carpet was widely broadcast on social media. President Xi Jinping personally invested a significant amount of time in one-on-one discussions related to economic development, including the Belt and Road Initiative. ${ }^{11}$ On the subject of tourism, it was noted that China has endorsed the FSM as an officially sanctioned tourist destination and announced its support for a range of infrastructure projects related to growing the FSM's fledgling tourism industry. The release of small block grants for each of the four states, as well as the gifting of a new inter-island aircraft, provided media headlines that substantially bolstered China's standing within FSM (Kaselehlie Press 2017). The December 2019 state visit by current FSM President David Panuelo followed a similar formula.

Neither the modest deliverables nor the public respect conveyed through such high-profile visits obscure China's strategic interests in the region. The Pacific's political leadership has a clear understanding of China's desire for strong bilateral relationships that will increase its influence. At the same time, official state visits like that of FSM's president provide a basis for comparison with Washington's overall lack of high-level attention to the FAS, and the Pacific region more generally. Indeed, while on some rare occasions Pacific Island leaders have had working meetings in the West Wing, there has never been a formal state visit to the White House for a Pacific Island leader or group of leaders. Over the last three decades, the US president has engaged with the Pacific Island leaders as a regional group on only four occasions, with each of these events taking place in Honolulu, Hawai i.

11 Another recent example of this personal engagement by China's leadership is Samoan Prime Minister Tuilaepa Sailele Malielegaoi's participation in the Davos Forum in Northern China. While in Beijing, he held talks with President Xi Jinping, who promised to work with Samoa on climate change issues and deepen ties between the two countries. 
Since establishing diplomatic ties with the FSM, China has undertaken a wide range of ODA projects. Chinese embassy discretionary grants frequently provide much-needed equipment. Larger infrastructure projects are funded from time to time and may, in some cases, be built by local construction companies. These include constructing official residences for government officials at the national and state levels, as well as providing ships for inter-island transport. Block grants for purposes specified by state governments are also a regular element of Chinese involvement. Educational institutions have benefited from high-profile projects, such as the popular FSM-China Friendship Sports Centre gymnasium built at the College of Micronesia in Pohnpei. Initially structured as a US\$3.8 million interest-free loan, it was subsequently announced as a grant. Other small grants and gifts are frequently noted in media accounts, such as solar streetlights for state capitals and library book donations covering a wide range of subjects on China.

Official contact between China's diplomats and state government officials and direct aid to local governments is valued because it bestows prestige on local officials, some of whom in time are elected to national offices. In 2016, for instance, the Chinese embassy donated US $\$ 277,844$ for the construction of a new gymnasium complex in Madolenihmw. In Pohnpei State alone, China has launched a pilot farm in Pohnlangas, constructed a greenhouse, initiated biogas projects as well as a mushroom demonstration farm (Peterson 2018).

The most ambitious Chinese investment proposal in FSM to date has been the plan to build a 10,000-room holiday resort and casino complex in the state of Yap, accompanied by direct airline connections to facilitate ease of travel for vacationers. ${ }^{12}$ Announcement of the endeavour in 2011 surprised Yap's citizenry and gave rise to considerable debate regarding the wisdom of building such a massive resort in a location with a population of some 11,000 on a relatively small island (Anderson 2011; Radio Australia 2012). In 2015, Yap's governor and a 12-member delegation made a 10-day trip to China. A reciprocal visit to Yap was made the same year by representatives of the Guangdong Friendship Association.

12 University of Guam Professor Donald Rubinstein at a public seminar on 8 May 2014 indicated that Chengdu Century City New International Exhibition and Convention Center Company Ltd's (better known as ETG) proposed Paradise concept plan consisted of the construction of an oceanfront resort complex including artificial offshore islands and bungalows built over the lagoon, golf courses, expanded airport and seaport facilities, 'an immense water reservoir system' and native towns where displaced Yapese would be relocated (Villegas Zotomayor 2014). 
With the neighbouring Republic of Palau having attracted nearly 90,000 Chinese tourists in 2016, Yap's potential for increased tourism presents an attractive business opportunity. However, the image of hordes of tourists adversely changing Yap's highly valued culture and traditions, as well as other potential environmental impacts, has resulted in the temporary shelving of the project. To the extent that most FSM citizens do not distinguish between official Chinese Government assistance and private sector initiatives, the controversial proposal seemingly undermined diplomatic efforts by China to demonstrate that it is a responsible and culturally sensitive Pacific development partner. $^{13}$ Still, the foregoing experiences exemplify China's interest in expanding its economic footprint in the FSM.

China's desire to foster enhanced engagement with FSM is also reflected in a pronounced increase in diplomatic activities. In August 2017, for example, Vice Minister of Foreign Affairs Zheng Zeguang visited Pohnpei with a high-level delegation and spoke to the FSM's political leaders. A central topic of the dialogue was the FSM Trust Fund that the government of the FSM may rely on, in conjunction with the Compact Trust Fund, if US economic assistance is not extended after 2023. It was noted that China has already made significant contributions to the FSM national trust fund in recent years and might be willing to further supplement the fund to help the FSM achieve greater self-reliance.

The vibrant diplomatic linkages between the FSM and China are likewise reflected in numerous 'people-to-people' programs. Mechanisms such as 'sister city' agreements are being established to strengthen relationships and promote investment. For example, the FSM's Sokehs Municipal Government and Zhongshan City recently signed a document designed to foster better relations and understanding between citizens of both countries. A similar relationship has been announced with Heilongjiang province, facilitated by a large visiting delegation that requested a reciprocal visit by the FSM's officials and entrepreneurs.

China has provided a steady stream of opportunities for young people. For many years, the FSM's students have availed of scholarship opportunities in China. In 2017, for instance, Yap State and Hainan

13 Another point of friction between Yap and a Chinese firm in 2014 centred on the illegal harvesting of sea cucumbers (beche-de-mer). It was also found that the company had failed to renew its business licence during the previous year (Yap State Government 2014). 
established a new sister province-state relationship, at which time Hainan made a commitment to provide 50 academic scholarships within the next five years for students from the FSM. In addition, a range of invitations were extended for youth exchanges and technical transfer exchanges. Small grants have been provided on a regular basis for athletic activities, including travel stipends and transit accommodations to fund the FSM's participation in the 2016 Olympics in Rio de Janeiro, Brazil.

An emerging and highly sensitive dimension of the FSM-PRC relationship in the post-2023 period focuses on the role China may play in discussions regarding Chuuk's (the FSM's largest state, population $48,500)$ interest in changing its political status to become a sovereign nation (Jaynes 2015). Throughout the FSM's history, there has been internal contestation between the four state governments and the national government over how to equitably distribute US Compact of Free Association funding. Chuuk government officials periodically intimate that if they were an independent nation Chuuk would stand to directly receive substantially more overseas development assistance from the US, China and other nations.

The US has consistently maintained that its relationship is with the national government in Kolonia and any movement by a state to secede would, if the state were no longer part of the federation, presumably mean an end to compact-related disbursements. While this understanding has implicitly buttressed national unity, the proposed 2023 reduction of economic support could weaken national cohesion and encourage dialogue with China on this issue. The Chuuk lagoon, one of the Pacific's largest and deepest, is of possible strategic interest to the PRC. It was once a critically important location for the Japanese Navy and remains a potentially important strategic naval asset.

None of the current activities or projects linking China and the FSM are outside the bounds of normal diplomatic and economic engagement. In comparative terms, the US and China have a similar range of cultural and diplomatic activities with the FSM that are intended to bolster bilateral relations. However, any significant diminution of US economic support could erode the strong bonds the US presently shares with the FSM and provide China significant new opportunities. 


\section{Republic of the Marshall Islands}

The strategic value of the RMI (population 53,000) to the US currently exceeds that of the FSM and Palau due to the long-term lease and major Department of Defense infrastructure investments on Kwajalein. From both historical and contemporary perspectives, the relationship between the two countries is complex. ${ }^{14}$ By some estimates, the US provides nearly 80 per cent of the RMI's annual budget. Overall economic support from Washington to the RMI from 2004 to 2023 is estimated to total US $\$ 1.5$ billion. In addition, the US is committed to paying US $\$ 18$ million per year in rent to the RMI Government through 2066 for exclusive longterm use of Kwajalein's Ronald Reagan Ballistic Missile Defense Test Site.

The Reagan Test Site is but one component of several critical defencerelated activities on Kwajalein (US GAO 2002). Facility investments in excess of US $\$ 1$ billion there over the past decade are indicative of both the importance of the base as well as the long-range US plans for its use. Current land rental agreements have options for renewal after 2066. There is no other similar type of major facility in the FAS, though there are currently discussions underway about leasing land in Palau for defencerelated purposes.

Strong diplomatic ties with the US and Taiwan are central elements of the RMI's foreign policy. In 1991, the RMI initially established relations with the PRC. This changed in November 1998 when formal diplomatic linkages were forged between the RMI and Taiwan, occurring during a period when several other Pacific nations such as the Kingdom of Tonga were dropping Taipei in favour of Beijing. Since that time, the two countries have promoted exchanges and cooperation in the areas of fisheries, agriculture, education, tourism, technology and investment.

Despite the lack of a formal diplomatic presence in Majuro, China has nonetheless launched investment initiatives. Most recently indicative of China's economic involvement in the RMI was the Rongelap Atoll Special Administrative Region (RASA) proposal. Following RASA's unveiling by

14 The US nuclear testing program in the Western Pacific detonated 67 blasts between 1946 and 1958. In 1987, the US Congress allocated US\$150 million to the RMI as compensation for nuclear radiation claims. Bikini Atoll residents received US\$75 million over 15 years with the remainder allocated to trust funds. In 1992, an additional US\$90 million was conveyed for the resettlement trust fund. Approximately US\$600 million has been paid as compensation and remediation for nuclear testing that occurred between 1946-58 (US Embassy Marshall Islands 2012). 
Rongelaps' mayor at the 2018 Asia World Expo in Hong Kong, news reports described the endeavour as a 'utopia for foreign investors featuring relaxed tax and visa requirements' (Smith 2018a). With a vision of making the atolls into a 'Singapore-like hub', Chinese websites reportedly noted as many as 1,000 houses had already been sold.

In November 2018, there was an unusual motion of no confidence against then RMI President Hilda Heine, purportedly based on the government's proposal to introduce a cryptocurrency as legal tender. President Heine narrowly prevailed, but indicated that the real issue was Chinese interests:

Really the vote of no confidence is about the so-called Rongelap Atoll Special Administrative Region, or RASA scheme, which is an effort by certain foreign interests to take control of one of our atolls and turn it into a country within our own country (Smith 2018b). ${ }^{15}$

While the RASA-enabling legislation has yet to be enacted and appears to face significant domestic and US opposition, this episode suggests how China-financed commercial endeavours may strongly influence domestic politics in small island societies.

China's strategy in the North Pacific has, in recent years, demonstrated an increased willingness to exercise its commercial influence in the form of punitive commercial actions, such as charging vessels flagged with the RMI ship registry higher fees when they enter Chinese ports. The RMI's vibrant ship registry program (second only to Panama) may face a significant loss of revenue if China continues this practice. ${ }^{16}$ As is detailed in the following, China has also sought to disrupt Palau's tourism-based economy by restricting its citizens' travel to Palau for holidays.

Although the US's ODA to the RMI is by far the largest, Taiwan has been effective in using instruments of soft power to advance its relationships with both Washington and Majuro. Taiwan's activities complement US activities in a manner that deftly helps to maintain amicable relations on all sides. Both grants and soft loans are included in Taiwan's RMI portfolio. For example, in 2016 the International Cooperation and Development Fund provided a US\$4 million loan for a new Home Energy Efficiency and Renewable Energy Project encouraging local residents to embrace renewable energy (The Marshall Islands Journal 2016).

15 See also Lorennij (2018).

16 US Department of State official, 22 April 2019. Interview with author. 
Similarly, Taiwan allocates discretionary funds to support many small but highly visible projects, such as the construction of outdoor multipurpose courts for sports and the installation of solar streetlights (The Marshall Islands Journal 2018). In partnership with the Bank of the Marshall Islands, Taiwan underwrites a popular micro-loan program. Since its inception in 2006, the program has issued some US $\$ 4$ million in loans to over 1,000 customers (ibid.). The Taiwan-supported Laura Farm is an experimental agriculture and aquaculture facility where pilot projects are tested for applicability to local atoll conditions.

Taiwan and the RMI have frequently highlighted the cultural ties between the two nations in terms of sharing a common Austronesian heritage and the socioeconomic benefits associated with the relationship. In recent years, Taiwan has also stressed its ability to provide high-quality specialised medical care through periodic in-country clinics as well as educational programs in Taipei. The I-Shou School of Medicine for International Students was established in 2013 as part of Taiwan's goal to increase local medical capacities among its diplomatic allies. There are presently 25 Marshall Islands students pursuing degrees in a variety of fields at universities in Taiwan.

As is true for citizens of the FSM and Palau, the RMI has benefited from visa-free entry to the US. It is thought that approximately 1,000 Marshall Islanders emigrate to the US each year, a significant feature of the RMI-US bilateral relationship that neither Taiwan nor China can easily replicate (Hezel 2013). As an increasing number of Marshall Islanders leave for employment in the US, the RMI 2011 Census of Population and Housing documents an increase in international migration to the RMI (Economic Policy, Planning, and Statistics Office 2012). Between 2006 and 2011, 1,434 individuals entered as migrants, with 80 per cent residing in the capital of Majuro. An estimated 43 per cent were from the US, while 9.6 per cent were from the PRC.

In light of the overwhelming long-term US presence in the RMI, it is unlikely that China will secure a diplomatic foothold. High economic dependency on the US suggests the RMI is unlikely to see a plausible alternative to maintaining its current diplomatic relationships. The most significant threat facing US military facilities in Kwajalein and the RMI as a whole is vulnerability to the effects of climate change. 


\section{Republic of Palau}

Palau is distinguished by its upward economic trajectory, having become one of the most successful economies in the Pacific. With the smallest population of the three FAS (approximately 22,000), Palau's pristine natural environment and favourable geographic location for East Asian visitors has been used to good advantage in building a dynamic tourism industry. Its success as an international visitor destination has also made Palau the most globalised North Pacific nation. By numerous measures it is among the most prosperous of the Pacific Island nations, with a gross national income per capita of approximately US $\$ 13,000$. Palau is ranked 60 out of 186 countries on the 2017 Human Development Index, the highest of any developing country in the Pacific. (In contrast, the FSM is ranked 131 and the RMI is ranked 106.) At the same time, however, Palau's tourism industry is vulnerable on two fronts: heavy reliance on tourists coming from a single country and dependence on foreign labour in the private sector.

Like the RMI, Palau since 1999 has maintained diplomatic relations with Taiwan. The evolution of Palau's foreign policy began in the early 1990s. Prior to independence, policymakers accepted invitations from China and Taiwan for informal talks. Decisions regarding its bilateral relationships were well considered and included extensive internal debate. ${ }^{17}$ Since that time, Palau has taken a leading regional role in promoting Pacific Island nations' relations with Taiwan, such as hosting the Taiwan-Pacific Allies Summit. During such occasions, Taiwan's sovereignty has been endorsed by the Pacific governments in attendance. The summit declarations have regularly underscored Taiwan's impressive achievements in political democratisation and called for Taiwan's participation in international organisations such as the UN and the World Health Organization.

Palau receives substantial ODA, primarily from the US, Japan, Taiwan and Australia. For fiscal years 2011-24, direct US funding support will total US\$229 million, as well as an estimated US\$36 million in other US federal programs and services. Total US support, including both direct economic assistance and projected discretionary program assistance, may by 2024 approach a total US $\$ 427$ million (Lum and Vaughn 2017). Estimates suggest Palau receives more than US $\$ 10$ million annually in

17 See Mita (2010). 
aid from Taiwan, often indicated by signs announcing infrastructure, agricultural or training projects funded by grant money from Taipei (Lyons 2018).

Among Palau's largest infrastructure projects since independence has been the circumferential road around Babeldaob, at a cost of over US\$144 million (US GAO 2008). US funding for the project was limited to 53 miles, with Taiwan funding completion of the ring. The US\$25 million Japan-Palau Friendship Bridge completed in 2001 is one of Japan's most visible aid contributions to Palau, connecting Koror to Babeldaob. Another major endeavour is the Taiwan-funded agricultural technical mission intended to advance Palau's commercial agricultural production and thereby reduce food imports. Israel has assisted Palau in a similar manner with projects focusing on fish farming, as well as in the field of medicine.

Yet it is the vibrancy of Palau's private sector that sets it apart from the FSM and the RMI. Drawing on historical linkages and investments from Japan, Palau constructed its first luxury resort in 1985. After independence, efforts were made to diversify the tourism market to include not only Japanese but also Koreans and Taiwanese. Palau's diplomatic relations and geographic proximity to Taiwan steadily increased the visitor flows from Taipei, which by 2012 had reached 39,695 annually. However, it was not long before Taiwanese travel agencies realised the potential for working with travel firms in mainland China to send even larger numbers of tourists (Hezel 2017).

Although the Chinese Government never designated Palau as an approved destination status (ADS) country, it allowed China-based tour agencies to promote group package tours there via commercial and charter flights. These tour groups rapidly came to constitute the largest share of Palau's tourism industry. Between 2011 and 2015, the number of Chinese tourists surged from 1,699 to 86,850 per year, or more than 50 per cent of annual visitor arrivals. Based on 2013 figures, the US\$41.4 million collected from gross revenue business taxes, personal income taxes, general import taxes and airport departure green fees were nearly equal to the total grant (US $\$ 42$ million) money received from the US, Taiwan and multiple other sources. ${ }^{18}$ In November 2017, however, the Chinese Government, without advance notice, ordered tour operators to stop selling package tours to Palau. Travel agencies in China were warned that sending package tour groups to

18 See Hezel (2017:39). 
locations without ADS status could lead to substantial fines. ${ }^{19}$ The sudden drop in revenues from Chinese tourists has severely hurt Palau's public and private sectors. Not unexpectedly, restoring outbound plane loads of tourists from China hinges on Palau establishing formal relations with Beijing and acceding to the One China policy. ${ }^{20}$ The foregoing suggests that Palau may in the future conclude that its relationship with Taiwan is not sustainable. With interest being shown by major Chinese investors, Palau could, in the absence of significant new US military and ODA investments, begin to seriously consider a change in diplomatic recognition. ${ }^{21}$

\section{Conclusion}

Washington appears to be gaining a new appreciation of the FAS's largely successful nation-building efforts, which have produced political and social stability. US plans to end major US economic support for basic services to the FSM and the RMI in 2023 are increasingly viewed by Department of Defense policy analysts as imperilling the returns on this long-term strategic investment. In light of the special relationship between the US and the FAS, as well as increasingly vigorous efforts by Western nations to restrain China globally, it is not surprising to observe the US taking measures to curtail China's drive to establish a more significant North Pacific presence.

Concurrently, there is a clear awareness by policymakers in the FSM, the RMI and Palau of the need for long-term strategic thinking. Recent actions suggest all three nations are open to a significant expansion of international engagement to advance their respective national interests. While the innovative compact relationships between the FAS and the US have clearly established mutually beneficial partnerships, this does not preclude forging closer alliances with other countries.

19 This development was reported in Lyons (2018).

20 A second potential area of vulnerability for Palau that may indirectly be subject to China's economic leverage focuses on Filipino 'guest workers'. Despite a rapidly expanding economy over the past two decades, there is an increasing dependence on foreign guest workers in Palau (including approximately 4,000 Filipino workers and approximately 1,000 Chinese workers). Of the approximately 5,000 non-Palauan workers in Palau, some 75 per cent are from the nearby Philippines, suggesting a level of self-imposed dependency on guest workers that is unknown in other Pacific Island nations (Alegado and Finin 2000). If China were to convince the Philippine government to reduce the number of overseas Filipino workers deployed to Palau, this contraction of the labour force could potentially be highly disruptive to Palau's tourism industry.

21 For a fuller explanation of the secretary of state's trip to Cook Islands, see Myers (2012). 
Despite the 2020 election of President Biden, a return to earlier US policies that were more accommodating to China's rise is highly unlikely. Similarly, other metropolitan countries in Oceania are also recalibrating their policies to more firmly contain Chinese expansionism through stronger coalitions and more deliberate shaping of the regional order. In particular, Australia and New Zealand's important economic ties with China will require both nations to hedge their Pacific stratagems vis-à-vis the PRC. At the same time, the strong Australia and New Zealand linkages with the US are all but certain to endure. Emboldened by recent developments, the FAS can be counted upon to deepen their engagement with the US while adroitly managing their respective relationships with Taiwan and China.

\section{References}

Alegado, D. and G. Finin 2000. Exporting People: The Philippines and Contract Labor in Palau. The Contemporary Pacific 12(2):359-70. doi.org/10.1353/ cp.2000.0039

Anderson, J.A. 2011. Chinese Investors Plan Major Hotel in Yap. Pacific Islands Report, 5 October. www.pireport.org/articles/2011/10/05/chinese-investorsplan-major-hotel-yap

Anderson, P. 2015. American Foreign Policy and Its Thinkers. London: Verso.

Asplund, A. and M. Soderberg M. (eds) 2017. Japanese Development Cooperation: The Making of an Aid Architecture Pivoting to Asia. New York: Routledge. doi.org/10.4324/9781315407746

Baraniuk, C. 2018. Marshall Islands Warned against Adopting Digital Currency. BBC News, 11 September. www.bbc.com/news/technology- 45485685

Buckley, C. and C. Horton 2019. Xi Jinping Warns Taiwan That Unification Is the Goal and Force Is an Option. The New York Times, 1 January. www. nytimes.com/2019/01/01/world/asia/xi-jinping-taiwan-china.html?search ResultPosition $=2$

Campbell, Kurt M. and R. Doshi 2021. How America Can Shore Up Asian Order. Foreign Affairs, 12 January. www.foreignaffairs.com/articles/united-states/202101-12/how-america-can-shore-asian-order

Cheng, Z. and I. Taylor 2017. China's Aid to Africa: Does Friendship Really Matter? New York: Routledge. 
China Economic Review 2018. Beijing Told to "Assess and Prevent Risks" in New Belt and Road Projects. 27 December. www.chinaeconomicreview.com/beijingtold-to-assess-and-prevent-risks-in-new-belt-and-road-projects/

Economic Policy, Planning, and Statistics Office 2012. RMI 2011 Census of Population and Housing. www.doi.gov/sites/doi.gov/files/migrated/oia/ reports/upload/RMI-2011-Census-Summary-Report-on-Population-andHousing.pdf

Finin, G.A. 2011. Power Diplomacy at the 2011 Pacific Islands Forum. Asia Pacific Bulletin, No. 136. Washington DC: East-West Center. www.eastwestcenter. org/publications/power-diplomacy-2011-pacific-islands-forum-pif

Finin, G.A. 2013. Envisioning the North Pacific Economies Post 2023. ADB Pacific Economic Monitor July:22-26.

Funaki, K. 2017. Official Development Assistance: Exploring Priority, Disbursement, Dependency and Leverage from the Perspectives of Three Pacific Island Countries. PhD thesis, Ritsumeikan Asia Pacific University.

Greenfield, C. and J. Barrett 2018. Payment Due: Pacific Islands in the Red as Debts to China Mount. Reuters, 31 July. www.reuters.com/article/us-pacificdebt-china-insight/payment-due-pacific-islands-in-the-red-as-debts-to-chinamount-idUSKBN1KK2J4

Hanlon, D. 1998. Remaking Micronesia: Discourses over Development in a Pacific Territory 1944-1982. Honolulu: University of Hawai'i Press.

Hezel, F.X. 2003. Strangers in Their Own Land: A Century of Colonial Rule in the Caroline and Marshall Islands. Honolulu: University of Hawai'i Press.

Hezel, F.X. 2006. Is That the Best You Can Do: A Tale of Two Micronesian Economies. Pacific Islands Policy, No. 1. Honolulu: East-West Center.

Hezel, F.X. 2013. FSM Micronesians on the Move: Eastward and Upward Bound. Pacific Islands Policy, No. 9. Honolulu: East-West Center.

Hezel, F.X. 2017. On Your Mark, Get Set...Tourism's Takeoff in Micronesia. Honolulu: East-West Center.

Jaynes, B. 2015. Chuuk State to Hold Secession Vote in March. Pacific Islands Report, 6 February. www.pireport.org/articles/2015/02/06/chuuk-state-holdsecession-vote-march

Kaselehlie Press 2017. Chinese-Made Aircraft Delivered to FSM. 1 December. www.kpress.info/index.php?option=com_content $\& v$ view $=$ article $\&$ id $=800$ : chinese-made-aircraft-delivered-to-fsm\&catid=8\&Itemid=103 
Kato, H., J. Page and Y. Shimomura (eds) 2016. Japan's Development Assistance: Foreign Aid and the Post-2015 Agenda. New York: Palgrave Macmillan.

Kuttner, R. 2018. Can Democracy Survive Global Capitalism? New York: W.W. Norton.

Lee, J. 2019. The Use of AID to Counter China's 'Djibouti Strategy' in the South Pacific. Washington: Hudson Institute.

Levy, J. 2008. Micronesian Government: Yesterday, Today and Tomorrow. Pohnpei: Micronesian Seminar.

Lian, Y-Z. 2019. Xi Jinping Wanted Global Dominance. He Overshot. The New York Times, 7 May.

Lorennij, K. 2018. Heine Survives Confidence Vote. The Marshall Islands Journal, 15 November. marshallislandsjournal.com/?p=6399

Lum, T. and B. Vaughn 2017. The Pacific Islands: Policy Issues. Congressional Research Service Report. Washington DC: Library of Congress, Congressional Research Service, 10.

Lyons, K. 2018. 'Palau Against China!': The Tiny Island Standing up to a Giant. The Guardian, 8 September.

Mita, T. 2010. Changing Attitudes and the Two Chinas in the Republic of Palau. In T. Wesley-Smith and E.A. Porter (eds), China in Oceania: Reshaping the Pacific? Brooklyn: Berghahn Books, 180-81.

Myers, S.L. 2012. Clinton Begins Asia Trip, Trying to Ease Tension with China. The New York Times, 1 September. www.nytimes.com/2012/09/02/world/asia/ clinton-tries-to-ease-tension-with-china-on-asia-trip.html/

Nguyen, M. and J. Pryke 2018. Exploring Taiwan's Aid to the Pacific. The Interpreter, 25 September. Lowy Institute. www.lowyinstitute.org/theinterpreter/exploring-taiwan-s-aid-pacific

Peterson, M. 2018. State of the State. Address to the Pohnpei State Legislature, Pohnpei, 6 March 2018.

Pompeo, M.R. 2019. Statement from Secretary Pompeo to the Micronesia Presidents' Summit. Speech at the Micronesia Presidents' Summit, Koror, 19 February. fj.usembassy.gov/statement-from-secretary-pompeo-tothe-micronesia-presidents-summit/

Radio Australia 2012. Large-Scale Yap Tourism Development Halted in FSM. Pacific Islands Report, 5 September. www.pireport.org/articles/2012/09/06/ large-scale-yap-tourism-development-halted-fsm 
Radio New Zealand 2018a. Marshall Islands Goes Visa-Free with Taiwan. 30 July. www.rnz.co.nz/international/pacific-news/362982/marshall-islands-goes-visafree-with-taiwan

Radio New Zealand 2018b. Asian Development Bank Scales up Pacific Presence. 20 September. www.radionz.co.nz/international/pacific-news/366926/asiandevelopment-bank-scales-up-pacific-presence

Radio New Zealand 2019. Senior US Officials Visit Three Micronesian Countries. 22 February. www.radionz.co.nz/international/pacific-news/383102/seniorus-officials-visit-three-micronesian-countries

Remengesau, T., Jr. 2019. Pacific Defense Pact Renewal Vital to the US Amid Rising Tension with China. The Hill, 17 May. www.thehill.com/blogs/ congress-blog/foreign-policy/444291-pacific-defense-pact-renewal-vital-tothe-us-amid-rising

Roy, D. 2019. Taiwan's Potential Role in the Free and Open Indo-Pacific Strategy: Convergence in the South Pacific. NBR Special Report \#77. Washington: The National Bureau of Asian Research.

Smith, M. 2018a. Remote Marshall Islands Atoll Plans to Become the 'Next Hong Kong'. Radio New Zealand, 21 September. www.rnz.co.nz/international/ pacific-news/366965/remote-marshall-islands-atoll-plans-to-become-thenext-hong-kong

Smith, M. 2018b. 'It Is Baseless' - Marshalls President, Facing Ouster, Blames Chinese Influence. Radio New Zealand, 9 November. www.radionz.co.nz/ international/pacific-news/375519/it-is-baseless-marshalls-president-facingouster-blames-chinese-influence

Stayman, A. 2009. US Territorial Policy: Trends and Current Challenges. Pacific Islands Policy, No. 5. Honolulu: East-West Center.

The Marshall Islands Journal 2016. ROC Backs Energy Loan Fund. 25 November. www.marshallislandsjournal.com/roc-backs-energy-loan-fund/

The Marshall Islands Journal 2017. US-Funded Jobs Get Moving. 13 January. www.marshallislandsjournal.com/us-funded-jobs-get-moving/

The Marshall Islands Journal 2018. Let There Be Light at Night. 12 April. www. marshallislandsjournal.com/?p=5644

Underwood, R. 2003. The Amended US Compacts of Free Association with the Federated States of Micronesia and the Republic of the Marshall Islands: Less Free, More Compact. East-West Center Working Papers. Pacific Islands Development Series No. 16, September. www.eastwestcenter.org/system/tdf/ private/PIDPwp016.pdf?file $=1 \&$ type $=$ node $\&$ id $=31948$ 
Underwood, R. 2017. The Changing American Lake in the Middle of the Pacific. Paper presented for the Peter Tali Coleman Lecture on Pacific Public Policy at the Georgetown University Center for Australian, New Zealand and Pacific Studies, 16 November.

US Embassy Marshall Islands 2012. The Legacy of US Nuclear Testing and Radiation Exposure in the Marshall Islands. mh.usembassy.gov/the-legacy-ofu-s-nuclear-testing-and-radiation-exposure-in-the-marshall-islands/

US GAO (US Government Accountability Office) 2002. Kwajalein Atoll Is the Key US Defense Interest in Two Micronesian Nations. Washington DC: GAO. www.gao.gov/new.items/d02119.pdf

US GAO (US Government Accountability Office) 2007. Compacts of Free Association: Trust Funds for Micronesia and Marshall Islands May Not Provide Sustainable Income. Washington DC: GAO. www.gao.gov/products/GAO07-513

US GAO (US Government Accountability Office) 2008. Palau's Use of and Accountability for US Assistance and Prospects for Economic Self-Sufficiency. www.gao.gov/assets/280/276299.pdf

US GAO (US Government Accountability Office) 2018. Compacts of Free Association: Actions Needed to Prepare for the Transition of Micronesia and the Marshall Islands to Trust Fund Income. Washington DC: GAO, 18-415.

Villegas Zotomayor, L. 2014. Mega-Casino Resort Project Reportedly 'Still on the Table' in Yap. Pacific Islands Report, 5 June. www.pireport.org/articles/ 2014/06/05/mega-casino-resort-project-reportedly-\%E2\%80\%98still-table $\%$ E2\%80\%99-yap

Wesley-Smith, T. and E. Porter (eds) 2010. China in Oceania: Reshaping the Pacific? New York: Berghahn Books.

World Bank 2017. Pacific Possible: Long-Term Economic Opportunities and Challenges for Pacific Island Countries. Washington DC: International Bank for Reconstruction and Development/The World Bank. documents. worldbank.org/curated/en/168951503668157320/Pacific-Possible-longterm-economic-opportunities-and-challenges-for-Pacific-Island-Countries

World Bank 2018. Micro Connections: Connecting the Federated States of Micronesia. www.worldbank.org/en/news/feature/2018/06/11/microconnections-connecting-the-federated-states-of-micronesia

Yap State Government 2014. Chinese Firm Has Licenses Revoked for Illegal Sea Cucumber Harvesting. News release, 14 July. www.pireport.org/articles/ 2014/07/22/chinese-firm-has-licenses-revoked-illegal-sea-cucumber-harvesting 
This text is taken from The China Alternative: Changing Regional Order in the Pacific Islands, edited by Graeme Smith and Terence Wesley-Smith, published 2021 by ANU Press, The Australian National University, Canberra, Australia.

doi.org/10.22459/CA.2021.05 